\title{
Nutritional interventions in refugee camps on Jordan's eastern border: assessment of status of vulnerable groups
}

I.M. Khatib, ' S.M. Samrah ${ }^{2}$ and F.M. Zghol ${ }^{3}$

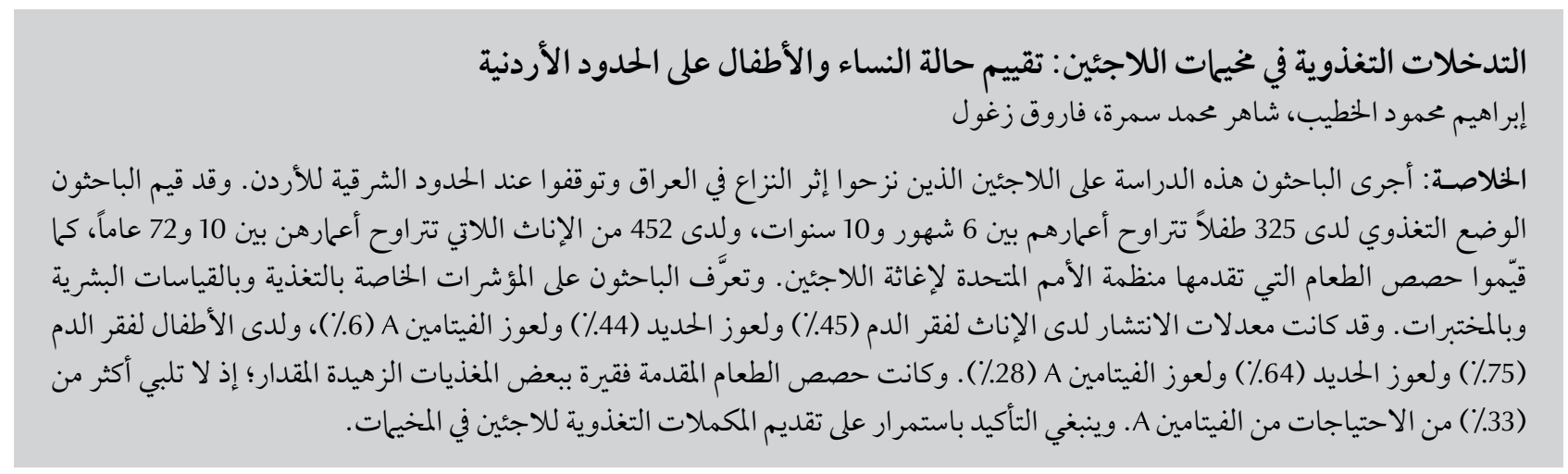

ABSTRACT This study was carried out on refugees who had fled the turmoil in Iraq and were hosted at the eastern border of Jordan. We assessed the nutritional status of 325 children aged 6 months-10 years and 452 females aged 10-72 years, and evaluated the food rations supplied by the UNHCR. Dietary, anthropometric and laboratory indicators were determined. For females and children respectively, prevalence rates were: anaemia $45 \%$ and $75 \%$, iron deficiency $44 \%$ and $64 \%$, and vitamin A deficiency $6 \%$ and $28 \%$. Rationed foods supplied little of some micronutrients: only $33 \%$ of vitamin A needs were met. Dietary supplementation for refugees in camps is always warranted.

Interventions nutritionnelles dans les camps de réfugiés à la frontière orientale de la Jordanie : évaluation du statut des groupes vulnérables

RÉSUMÉ La présente étude a été réalisée auprès de réfugiés qui avaient fui le chaos en Iraq et étaient accueillis à la frontière orientale de la Jordanie. Nous avons analysé l'état nutritionnel de 325 enfants âgés de six mois à 10 ans et de 452 femmes âgées de 10 à 72 ans et évalué les rations alimentaires fournies par le Haut Commissariat des Nations Unies pour les réfugiés (HCR). Des indicateurs alimentaires, anthropométriques et de laboratoire ont été définis. Pour les femmes et les enfants, respectivement, les taux de prévalence étaient les suivants : anémie $45 \%$ et $75 \%$, carence en fer $44 \%$ et $64 \%$, carence en vitamine A $6 \%$ et $28 \%$. Les aliments composant la ration n'apportaient qu'une petite partie des micronutriments : seulement $33 \%$ des besoins en vitamine A étaient satisfaits. Les compléments alimentaires destinés aux réfugiés dans les camps sont toujours nécessaires.

${ }^{7}$ Department of Public Health and Community and Family Medicine; ${ }^{2}$ Department of Internal Medicine, Faculty of Medicine; ${ }^{3}$ Faculty of Pharmacy, Jordan University of Science \& Technology, Amman, Jordan (imdk@just.edu.jo; khatibmd@orange.jo).

Received: 26/07/2009; accepted: 04/08/2009 


\section{Introduction}

In developing countries, nutritional inadequacies, especially those of micronutrients, often imperil growth in children [1-3] Stunted growth in early childhood is associated in some communities with increased mortality [4]; in others it impedes development and adversely influences cognitive abilities $[5,6]$, adds to morbidity [7] and contributes to dysfunction in individuals [8]. While iron deficiency anaemia (IDA) remains the major facet of nutritional inadequacy in developing nations, non-ocular vitamin A deficiency (VAD) has been spotlighted in recent years. Due to its confounding effect on the haematological profile, VAD can influence anaemia indicators and overestimation of IDA usually results $[7-10]$. Consequently, the study of VAD in nutritional surveys is essential [8] for at least 2 reasons: its contribution to the disease burden, including diarrhoea and infections, and its interaction with IDA [9]. In developing parts of the Middle East region, IDA may imply co-existing zinc deficiency $[5,11,12]$. With socioeconomic constraints determining most nutritional challenges in the developing world [1-3], food supply ought to become a prime component of national security strategies. In emergencies such as when underprivileged people are displaced to live in refugee camps, the food issue becomes crucial [13]. In refugee camps, children are the most vulnerable to undernourishment; however, broadening the risk view further to include other groups is warranted [14].

\section{Setting}

At the outbreak of the internal Iraqi war in April 2003, more than 1600 of those who fled the conflict sought refuge in Jordan on the eastern border with Iraq. Until December 2008, when the last batches departed to other countries, these refugees settled in 2 adjacent camps: Ruwayshed and Al-Karamah (no-man's land). Equidistant from the Iraqi and Jordanian urban areas, the camps were in the middle of the Shaam Badia (desert), which separates Jordan from 3 neighbouring countries: Syria, Iraq, and Saudi Arabia. The refugees were Iranian, Iraqi, Palestinian and Sudanese families, along with a minority of single men.

The Office of the United Nations High Commissioner for Refugees (UNHCR) assumed full responsibility in managing their daily affairs, including health care and camp hygiene. In supplying food rations, the UNHCR used a Food Ration Reference List (FRRL), as the reference yardstick. To manage the food supply and ensure rations reached families as planned, the UNHCR assigned intermediary agents, refugees from the camps, who were elected as representatives at the UNHCR field office. UNHCR services provision in the camps had assistance from the Cooperative for Assistance and Relief Everywhere, Inc., and the support of the Jordanian authorities. The United Nations Children's Fund (UNICEF) provided the clinic tents and medical supplies.

\section{Study scope}

The design proposal of this crosssectional study had 3 major stages. First was the hypothesis that the health of vulnerable refugees, starting with the cohorts of children and adult women of reproductive age, could be declining due to insufficient nutrition from food rations [13]. Second, hypothesis testing relied on assessing child growth, screening for anaemia and relevant deficiencies in risk groups, and evaluating food rations. Third was the reporting of results to stakeholders concerned in the refugees' affairs.

\section{Methods}

On the first field working day in May 2004, UNHCR officers revealed that the flux of refugees in both camps was still actively going on. For security reasons, UNHCR agreed only to provide selected demographic statistics on camps, describing them as "estimates". The 1600 refugees on Jordan's eastern borders were a heterogeneous collection of Middle Eastern people, having no conventional demographic population structure.

Due to the limited numbers of families, it was decided that all apparently healthy refugees from the nutritionally vulnerable groups, basically children and women of reproductive age, were eligible for inclusion as study subjects. Eligibility had to be completed by presenting consent signed by the participant or by a parent. During fieldwork, all adult women (homemakers) who came to the CARE tent with written consent, were enrolled (the CARE tent was the only focal point for homemakers in each of the 2 camps to get information about prospects and everything else concerning the families living in the camps; the CARE workers assisted in publicising this study and distributing the consent forms of to those willing to participate).

The UNHCR Ruwayshed field office provided only estimates of numbers of refugees. The estimated number of children $>6$ months of age and $<10$ years was 350, 160 of whom were $<5$ years. The estimated number of eligible females was 480,270 aged $18-45$ years, 50 older women and 160 adolescents. Participation was voluntary, and the study involved 777 participants from 2 different cohorts: 325 children under 10 years of age and 452 females aged $\geq 10$ years. The first cohort comprised 152 children under 5 years of age but older than 6 months and 173 school-age children. All apparently non-ill children who showed up with their mothers with signed consent forms were included in the study. The reason for excluding young infants was the fact that most babies under 6 months old were breast fed. The females comprised 247 adults aged 18-45 years (19 of these were 
pregnant women who were excluded from the final statistical analyses since they belonged to a different clinical group), 47 older women ( $46-72$ years) and 158 adolescent girls ( $10-17$ years). According to UNHCR records, the sample was estimated on average at $>90 \%$ of both cohorts.

Haemoglobin and haematocrit testing were done for all subjects. Excepting the older women, anthropometric measurements (length or height and weight) were taken for all groups. We recruited 156 female home-makers to administer a short questionnaire: the interviews with the majority of participants could only be accomplished with help from a female translator.

All refugees were briefed on the nature of the survey 2 days before fieldwork, with emphasis placed on the voluntary aspect of blood sampling for laboratory assessment. Venepuncture was used on only 137 women and children; this random sample involved children under 5 years old (45), schoolage children (29), adult women of reproductive age (33), pregnant adult women (13), and older women (17). Finger or heel pricking for haematological testing was used for 219 children and 398 female participants; 32 children and 8 women declined to give any blood. Laboratory analyses included tests for haemoglobin $(\mathrm{Hb})$ and haematocrit, and measuring the concentration of serum ferritin (SFC), retinol (SRC, vi$\operatorname{tamin} A$ ), and $\alpha$-tocopherol (STC, vita$\min$ E). Testing serum a1-glycoprotein (AGP), an inflammation biomarker, was done for judgment on the impact of the illness burden on nutritional indicators, and calculating correction factors where indicated $[15,16]$.

From random visits to households, in the 2 camps, we collected 20 samples of table salt. These were tested for iodine content (test solution: MBI-Kits International, India). Other dietary data were all drawn from the FRRL, the basis for food distribution in the camps.

\section{Data collection}

Field work started in May 2004. The study questionnaire was written in English and Arabic. We recruited female translators from among the refugees. As homemakers arrived at the CARE-tent they were invited to participate: anthropometric measurements and blood samples were taken and questionnaires administered. WHO-supported anthropometric procedures $[11,12]$ were applied with measurement standardization implemented from the first day.

Logistic limitations necessitated performing all laboratory tasks on the spot. The field laboratory capability undertook 4 consecutive tasks: blood collection, spectrophotometric $\mathrm{Hb}$ testing by the Drabkins (cyanmethaemoglobin) method, haematocrit test, and separation of serum samples. The sera were kept in cryovials in Ruwayshed Hospital freezers. On the final fieldwork day, the sera were transported via icebox to the Metabolic Laboratory at Jordan University of Science and Technology. Serum ferritin was tested using the chemiluminescent immunometric assay (Immulite 1000). The HPLCmethod used in testing serum retinol produced the $\alpha$-tocopherol chromatogram [17]. Reliability of readings was monitored using quality control sera (National Institute of Standards \& Technology, Gaithersburg, Maryland) for low and high levels.

\section{Statistical analyses}

Anthropometric indices and statistics on stunting, wasting, and underweight were computed using ANTHRO software for paediatric anthropometry $[11,12]$. For anthropometric indices, the cut-off point used for identifying deficits was $z$-score $<-2$. Diagnosis of anaemia was made if $\mathrm{Hb}$ concentration was $<120 \mathrm{~g} / \mathrm{L}$. A diagnosis of iron deficiency was assumed if serum ferritin concentration was $<10 \mu \mathrm{g} / \mathrm{L}$ or mean corpuscular haemoglobin concentration $(\mathrm{MCHC})$ index was $\leq 30 \mathrm{~g} / \mathrm{dL}$.
The cut-off point for diagnosis of deficiency was $200 \mu \mathrm{g} / \mathrm{L}$ for vitamin A and $5 \mathrm{mg} / \mathrm{L}$ for vitamin $\mathrm{E}$.

Other analyses were run using SPSS, version 4 . Results of analyses were recorded as means and percentages. Differences between groups were explored using the Student $t$-test for independent samples along with Spearman's correlation analysis. Differences were considered significant if the $P$-value was $<0.05$. For labelling a disorder as being of public health significance, the study adopted the "15\% prevalence" as the cut-off. This was inferred from the yardstick recently suggested for use with VAD [10].

The study protocol obtained approval and support from the Ethical Committee for Research on Humans of the Jordan University of Science and Technology Medical School, UNICEF Amman Office, and the Mafraq General Health Directorate, representing the Jordanian Ministry of Health (MOH). UNHCR field officers in Ruwayshed offered to provide all support to the survey provided they were pre-informed of survey field plans. The UNHCR coordinated all the intra- and inter-camp movements of the research team.

\section{Results}

At the onset of fieldwork, the UNHCR supplied some background documents, including the FRRL table, which shows all the rationed foods (Table 1).

Based on the valid responses to the questionnaire, a spectrum of background information was obtained. About one-fifth of adult refugees held a high school or higher diploma; the rest were educated to elementary school level.

More than $90 \%$ of refugee homemakers (142 of the 156 women) reflected in their responses recognition of the UNHCR efforts to make living in both camps secure and tolerable. They described the earlier FRRL food basket, 


\begin{tabular}{|c|c|c|c|c|c|c|c|c|}
\hline Ration composition & $\begin{array}{l}\text { Ration } \\
(\mathrm{g} / \mathrm{p} / \mathrm{d})\end{array}$ & $\begin{array}{c}\text { Energy } \\
\text { (kcal) }\end{array}$ & $\begin{array}{l}\text { Protein } \\
\text { (g) }\end{array}$ & $\begin{array}{l}\text { Fat } \\
\text { (g) }\end{array}$ & $\begin{array}{c}\text { Calcium } \\
(\mathrm{mg})\end{array}$ & $\begin{array}{l}\text { Iron } \\
\text { (mg) }\end{array}$ & $\begin{array}{c}\text { Vitamin A } \\
\text { (IU) [ug] }\end{array}$ & $\begin{array}{c}\text { Vitamin } B_{2} \\
(\mathrm{mg})\end{array}$ \\
\hline Rice, lightly milled, parboiled & 80 & 291 & 5.6 & 0.5 & 5 & 1.9 & 0 & 0.02 \\
\hline Sugar & 50 & 200 & 0.0 & 0.0 & 0 & 0.0 & 0 & 0.00 \\
\hline Pasta macaroni & 8.5 & 30 & 1.0 & 0.2 & 2 & 0.1 & 0 & 0.00 \\
\hline Corned beef & 9 & 21 & 2.3 & 1.3 & 5 & 0.4 & 0 & 0.02 \\
\hline Beans, small red, USA & 7 & 25 & 1.5 & 0.1 & 11 & 0.5 & 0 & 0.01 \\
\hline Canned cheese & 8 & 28 & 1.8 & 2.2 & 50 & 0.0 & $32[9.6]$ & 0.04 \\
\hline Vegetable oil (unfortified) & 27 & 240 & 0.0 & 27.0 & 0 & 0.0 & 0 & 0.00 \\
\hline Salt & 10 & 0 & 0.0 & 0.0 & 0 & 0.0 & 0 & 0.00 \\
\hline Tea & 8 & 3 & 0.8 & 0.0 & 2 & 0.1 & 0 & 0.03 \\
\hline Lentils & 9 & 30 & 2.5 & 0.1 & 5 & 0.8 & $4[1.1]$ & 0.02 \\
\hline Beans, kidney USA & 9 & 30 & 2.1 & 0.1 & 13 & 0.7 & $1[0.2]$ & 0.02 \\
\hline Bread, white & 380 & 992 & 29.3 & 7.6 & 141 & 6.5 & 0 & 0.23 \\
\hline Tomato & 100 & 21 & 1.0 & 0.2 & 10 & 0.6 & $750[225.0]$ & 0.04 \\
\hline Citrus & 100 & 49 & 0.8 & 0.3 & 38 & 1.1 & $395[115.0]$ & 0.05 \\
\hline Onion & 100 & 41 & 1.2 & 0.1 & 27 & 0.8 & 0 & 0.04 \\
\hline Eggplant & 100 & 32 & 1.0 & 0.2 & 14 & 1.3 & $57[17.0]$ & 0.05 \\
\hline Potato, sweet, yellow & 100 & 121 & 1.6 & 0.2 & 33 & 2.0 & $2100[620.0]$ & 0.04 \\
\hline Ration total & 898 & 2154 & 52.6 & 40.0 & 355 & 16.8 & 3338 [988.0] & 0.61 \\
\hline Minimum requirements & - & 2100 & 52.5 & 40.0 & 450 & 22.0 & $1650[500.0]$ & 1.40 \\
\hline$\%$ supplied by ration & - & 103 & 100.0 & 100.0 & 79 & 77.0 & 202 [197] & 43.00 \\
\hline
\end{tabular}

USA Dietary Reference Intake (DRI) was the reference for calculating nutritional values. Source: data sheet submitted by UNHCR Office in Ruwayshed. The Recommended Dietary Allowance (RDA) values included in the DRI tables were used as the reference for calculating individual nutritional intakes. $g / p / d=$ grams per person per day.

which they had received upon arrival at the camps more than a year previously, as different and richer. They had been informed that reports of an outbreak of avian influenza were the cause for excluding fresh meat from the FRRL. Half of the respondents wished to see olive oil replacing vegetable oil in the list, but only less than $5 \%$ admitted to missing fresh meat in meals.

Women who became new mothers during the period of stay in the camps reported receiving full antenatal care that ended with hospital deliveries. More than $95 \%$ of mothers initiated breastfeeding after delivery, with about 50\% continuing the practice beyond 1 year.

Episodes of childhood diarrhoea and respiratory tract infection were described as mild and of short duration. In the previous month, these affected about $13 \%$ (4 out of 30 ) of the children under 2 years and $9 \%$ (11 out of 119 ) of the children under 5 years.
On self-reporting of personal health, $88 \%$ (137 out of 156) of homemakers complained of $\geq 1$ of the importunate health disorders. As the women had to report the most bothersome complaint, they could roughly be distributed into specific categories: 33 (21.2\%) had bone pain problems, 17 (10.9\%) gastrointestinal upsets, $25(1.06 \%)$ systemic illnesses, 24 (15.4\%) neurological or psychological disorders, 12 (7.7\%) miscellaneous allergies and 26 (16.7\%) had non-specific complaints of general pain and weakness.

Prevalence of stunting in the children under 10 years old was moderate, averaging $12 \%$; wasting was about $1.8 \%$ and underweight $6.8 \%$. No significant sex-related anthropometric differences were found.

Tables 2-4 show the anaemia and vitamin A status of the participants. The mean and median values in respective order for $\mathrm{Hb}$ concentration were 117 [standard deviation (SD) 13] g/L and $118 \mathrm{~g} / \mathrm{L}$, for serum vitamin A (SRC) 263 (SD 49) $\mu \mathrm{g} / \mathrm{L}$ and $247 \mu \mathrm{g} / \mathrm{L}$, and for serum ferritin 21.1 (SD 13.8) $\mu \mathrm{g} / \mathrm{L}$ and $14.7 \mu \mathrm{g} / \mathrm{L}$ (Table 2).

In accord with contemporary research $[15,16]$, conducting "high versus normal" comparisons of serum AGP values indicated a need for using a correction factor of 0.7 for ferritin readings for children. The 2-tailed test showed that significant Spearman correlations of SRC were positive with each of haemoglobin $(r=0.60, P<0.001)$, serum $\alpha$-tocopherol and ferritin $(r=0.21, P$ $<0.05)$, but negative with serum AGP $(r=-0.21, P<0.05)$. Serum ferritin correlated positively with $\mathrm{Hb}(r=0.24, P$ $<0.01)$, but weakly with AGP $(r=0.18$, $P<0.055)$. The prevalence rates for anaemia $(\mathrm{Hb}<120 \mathrm{~g} / \mathrm{L})$ ranged from $46 \%$ in adolescent and postmenopausal females to $75 \%$ in children under 5 years. Assessed by ferritin level, prevalence of 


\begin{tabular}{|c|c|c|c|c|c|c|c|}
\hline \multirow[t]{3}{*}{ Variable } & \multicolumn{2}{|c|}{ All subjects } & \multicolumn{2}{|c|}{ Children } & \multirow{3}{*}{$\begin{array}{c}\text { Girls } \\
\text { 10-17 years } \\
\text { Mean (SD) }\end{array}$} & \multicolumn{2}{|c|}{ Adult women } \\
\hline & & & $<5$ years & $5-<10$ years & & $18-45$ years & $>45$ years \\
\hline & Mean (SD) & Median & & & & & \\
\hline $\operatorname{SRC}(\mu \mathrm{g} / \mathrm{L})$ & $263(79)$ & 247 & $240(52.8)$ & $233(56.0)$ & ND & $295(82.8)$ & $322(110.7)$ \\
\hline$n$ & 124 & & 45 & 29 & 0 & 33 & 17 \\
\hline $\mathrm{STC}(\mathrm{mg} / \mathrm{L})$ & $7.80(5.21)$ & 6.89 & $6.98(1.28)$ & $6.33(1.29)$ & ND & $9.86(9.56)$ & $8.18(2.7)$ \\
\hline$n$ & 123 & & 44 & 29 & 0 & 33 & 17 \\
\hline $\operatorname{SFC}(\mu \mathrm{g} / \mathrm{L})$ & $21.1(13.8)$ & 14.7 & $19.0(12.9)$ & $15.7(9.5)$ & ND & $18.2(15.7)$ & $36.6(35.2)$ \\
\hline$n$ & 117 & & 42 & 26 & 0 & 32 & 17 \\
\hline $\mathrm{Hb}(\mathrm{g} / \mathrm{L})$ & 117 (13) & 118 & 111 (11.1) & 115 (12.0) & $120(12.4)$ & 119 (14.2) & 118 (12.7) \\
\hline$n$ & 737 & & 122 & 171 & 154 & 243 & 47 \\
\hline $\mathrm{MCHC}(\mathrm{g} / \mathrm{dL})$ & $30.46(2.04)$ & 30.43 & $30.38(1.88)$ & $30.43(1.60)$ & $30.67(1.66)$ & $30.35(2.56)$ & $30.73(2.01)$ \\
\hline$n$ & 737 & & 122 & 171 & 154 & 243 & 47 \\
\hline
\end{tabular}

$S D=$ standard deviation; $N D=$ not done; $S R C=$ serum retinol concentration; $S T C=$ serum $\alpha$-tocopherol concentration; SFC = serum ferritin concentration; Hb $=$ haemoglobin concentration; $M C H C=$ mean corpuscular haemoglobin concentration.

Spearman correlations, using the 2-tailed significance test: $S R C$ with $\mathrm{Hb}(\mathrm{r}=0.60, \mathrm{P}<0.001), \operatorname{SRC}$ with $S F C(\mathrm{r}=0.37, \mathrm{P}<0.001)$, SFC with Hb $(\mathrm{r}=0.23, \mathrm{P}<0.01)$

iron deficiency was around $51 \%$ (Table 3). Women of reproductive age had a lower anaemia rate $(50.6 \%)$ compared to the school age children $(63.5 \%)$ and children under 5 years $(74.6 \%)$ (Table 3 , Figure 1). Only $6 \%$ of women $\geq 46$ years had compared to $12 \%$ of women of reproductive age. Fewer women of reproductive age suffered from iron deficiency (43.8\%) than other groups. More than $50 \%$ of children were iron deficient while about $28 \%$ had VAD (Table 3). If borderline SRC values are considered within the risk frame, analyses for VAD threat would then encompass about $85 \%$ of the children under 5 years and $90 \%$ of the school-age children.

Across groups, a trend of low serum vitamin $\mathrm{E}$ was noted; if borderline STC values were considered within the risk range, then threat of vitamin $\mathrm{E}$

\begin{tabular}{|c|c|c|c|c|c|c|c|}
\hline \multirow[t]{3}{*}{ Variables } & \multicolumn{2}{|c|}{ All } & \multicolumn{2}{|c|}{ Children } & \multirow{3}{*}{$\begin{array}{c}\text { Girls } \\
\text { 10-17 years } \\
\%\end{array}$} & \multirow{2}{*}{\multicolumn{2}{|c|}{$\begin{array}{c}\text { Adult women } \\
18-45 \text { years }>45 \text { years }\end{array}$}} \\
\hline & & & $<5$ years & $5-<10$ years & & & \\
\hline & No. & $\%$ & $\%$ & $\%$ & & $\%$ & $\%$ \\
\hline \multicolumn{8}{|c|}{ Vitamin A status, $S R C \mu g / L(\mathrm{n}=124)$} \\
\hline$<200$ (deficient) & 26 & 21.0 & 28.9 & 27.6 & ND & 12.1 & 5.9 \\
\hline $200-<300$ (borderline) & 61 & 49.2 & 55.6 & 62.1 & ND & 36.4 & 35.3 \\
\hline $300+$ (normal & 37 & 29.8 & 15.6 & 10.3 & ND & 51.5 & 58.8 \\
\hline \multicolumn{8}{|c|}{ Vitamin E status, STC mg/L $(\mathrm{n}=123)$} \\
\hline$<5$ (deficient) & 15 & 12.2 & 11.4 & 13.8 & ND & 6.1 & 17.6 \\
\hline $5-<10$ (borderline) & 94 & 76.4 & 88.6 & 86.2 & ND & 66.7 & 52.9 \\
\hline $10+($ normal & 14 & 11.4 & 0.0 & 0.0 & ND & 27.3 & 29.4 \\
\hline \multicolumn{8}{|c|}{ Haemoglobin status, $\mathrm{Hbg} / L(\mathrm{n}=737)$} \\
\hline$<120$ (anaemic) & 414 & 56.2 & 74.6 & 63.1 & 45.4 & 50.6 & 46.8 \\
\hline $120+($ normal $)$ & 323 & 43.8 & 25.4 & 36.8 & 54.5 & 49.4 & 53.2 \\
\hline \multicolumn{8}{|c|}{ Iron status (ferritin indicator) $S F C \mu g / L(\mathrm{n}=119)$} \\
\hline$<10$ (deficient) & 61 & 51.3 & 50.0 & 64.3 & ND & 43.8 & 47.1 \\
\hline $10-<15$ (borderline) & 19 & 16.0 & 16.7 & 28.6 & ND & 6.3 & 11.8 \\
\hline $15+$ (normal) & 39 & 32.8 & 33.3 & 7.1 & ND & 50.9 & 41.1 \\
\hline \multicolumn{8}{|c|}{ Iron status, $(M C H C$ index $) g / d L(n=737)$} \\
\hline$\leq 30$ (deficient) & 304 & 41.2 & 44.3 & 40.4 & 30.0 & 48.1 & 38.3 \\
\hline$>30$ (normal) & 433 & 58.8 & 55.7 & 59.6 & 70.0 & 51.9 & 61.7 \\
\hline
\end{tabular}

$S R C=$ serum retinol concentration; $N D=$ not done; STC = serum $\alpha$-tocopherol concentration; $H b=$ haemoglobin concentration; SFC = serum ferritin concentration; $M C H C=$ mean corpuscular haemoglobin concentration. 


\begin{tabular}{|c|c|c|c|c|}
\hline \multirow[t]{2}{*}{ Variable } & No. & Mean & SD & $P$ \\
\hline & \multicolumn{4}{|c|}{ Children 6 months $-<10$ years } \\
\hline \multicolumn{5}{|c|}{ Haemoglobin concentration $(\mathrm{g} / \mathrm{L})$} \\
\hline Vitamin A deficient & 21 & 104 & 9.4 & $<0.01$ \\
\hline Normal vitamin A & 51 & 111 & 11.6 & \\
\hline \multicolumn{5}{|c|}{ Serum vitamin $A$ concentration $(\mu \mathrm{g} / \mathrm{L})$} \\
\hline Anaemic & 36 & 221 & 44 & $<0.01$ \\
\hline \multirow[t]{2}{*}{ Normal $\mathrm{Hb}$ level } & 36 & 254 & 59 & \\
\hline & \multicolumn{4}{|c|}{ Women $18-45$ years } \\
\hline \multicolumn{5}{|c|}{ Haemoglobin concentration $(\mathrm{g} / \mathrm{L})$} \\
\hline Vitamin A deficient & 4 & 97 & 6 & $<0.001$ \\
\hline Normal vitamin A & 29 & 115 & 14 & \\
\hline \multicolumn{5}{|c|}{ Serum vitamin A concentration $(\mu g / L)$} \\
\hline Anaemic & 15 & 238 & 57 & $<0.001$ \\
\hline Normal Hb level & 18 & 310 & 66 & \\
\hline
\end{tabular}

${ }^{a}$ Reproductive age

$S D=$ standard deviation .

deficiency would cover all children and $>70 \%$ of adult women (Table 3 ). Among adolescent girls, $11.6 \%$ were stunted, $45.4 \%$ anaemic and $30 \%$ iron deficient (using the MCHC index).

Some of the inter-category comparative analyses showed statistical differences. Anaemia in children with normal vitamin $\mathrm{A}$ status was milder (mean $\mathrm{Hb}$ $=111 \mathrm{~g} / \mathrm{L})$ than in those who were vitamin $\mathrm{A}$ deficient (mean $\mathrm{Hb}=104$ $\mathrm{g} / \mathrm{L})(P<0.01)($ Table 4$)$. Anaemic children had lower SRC $(221 \mu \mathrm{g} / \mathrm{L})$ than non-anaemic children $(254 \mu \mathrm{g} / \mathrm{L})$ $(P<0.01)$. In reproductive-age women, the link between vitamin A status and anaemia was more evident.

Food distribution was governed by the UNHCR standard of $2100 \mathrm{kcal}$ requirement for adults. The FRRL (Table 1) was customized to meet the energy needs of sedentary adults, a description that typically matched the refugees in both camps. It included a variety of vegetables and fruits for their $\beta$-carotene supply. Close goitre inspection and table salt testing excluded the possibility of iodine deficiency at an early stage. However, a few features in the FRRL deserve highlighting. First, corned beef
$(9 \mathrm{~g} /$ person) replaced fresh meat along with the addition of more legumes to the rations; this provided only $2.3 \mathrm{~g}$ protein and $<0.5 \mathrm{mg}$ iron. Second, some micronutrients were supplied at marginal or even low levels compared with the dietary reference intake (DRI) [18]; these were calcium (79\%), iron $(77 \%)$, riboflavin $\left(\mathrm{B}_{2}\right)(43 \%)$, and vitamin A (33\%). In calculating FRRL contribution of vitamin A estimated in retinol equivalents (REs), the figure 3.33 was used for converting IU, mostly from $\beta$-carotene to RE units. Third, total FRRL-fat constituted $<20 \%$ of the rationed calories (Table 1).

\section{Discussion}

The basic limitations in this study were the small numbers of targeted refugees and the funding constraint. Expanding the study to a higher level, quantitatively and qualitatively, could not be done without extra financial obligations. The recurrent electricity failure in many tents across large sectors of the camps led to the cancellation of plans for working in the outreach within the camps.
Management of health and nutrition affairs of the Iraqi crisis refugees by the UNHCR had many achievements but some deficiencies. There was nearly total satisfaction among refugees over food rationing and distribution. Incidence of childhood diseases was quite low. Compared with neighbouring communities [19], refugee children had relatively better somatic growth. However, the compromised nutritional status of vulnerable refugees and certain gaps observed in the food rations prompted speculation over the causes. Although mild on severity scales, VAD prevalence in children exceeded the $15 \%$ cut-off, which indicated a VAD emergency [10]. The same conclusion could apply to anaemia. It seemed that the hasty exclusion of meat due to the avian influenza outbreaks created confusion while modifying the FRRL. The importance of meat as a rich source of micronutrients, especially iron and zinc, was most probably overlooked. Legumes cannot replace meat in this respect. Besides, the FRRL did not supply enough of the major micronutrients, e.g., calcium, iron, and riboflavin. With the FRRL rendered almost plant-based, and iron becoming marginally supplied, zinc inadequacy could also be assumed.

Calculation errors were also detected. According to the FRRL, vitamin A supply was incorrectly assumed to provide enough of the $\mu \mathrm{g}$ REs. Derived mainly from $\beta$-carotene foods at a 3338 IU level, the supply would correspond accurately to $333.8 \mu \mathrm{g}$ REs $[20,21]$, and that provided only $33 \%$ of the DRI for adults and $80 \%$ for children around the age of 10 years. The year 2002 DRIs [18] set the dietary fat ranges (as \% of total energy intake) for different age groups at variable levels: $30 \%-40 \%$ for the 1-3-year-old children, 25\%-35\% for the 4-18-year-olds and 20\%-35\% for adults. As calculations on the fat yield of many plant foods gave no margin for securing adequacy; this could lead to the ration falling below minimal 
recommended levels. Increasing fat consumption was indicated since this would improve bioavailability of dietary retinol and $\beta$-carotene, and other fat soluble vitamins.

\section{Conclusions}

Assuming that neither theft nor vandalism of aid foods was suspected, the FRRL was barely adequate to sustain proper nutritional health, especially for vitamin A needs. The dilemma of the Iraqi crisis refugees was difficult since, in the middle of the desert, they had no chance to farm, raise livestock, or provide for themselves. Ambitions for optimizing nutritional intervention outcomes in refugee camps can be realized only by periodic technical reviews. This survey recommended adding 2 major elements to the relief plans. First, the ration food items may not be always possible to purchase from local markets (e.g., seasonality); therefore, FRRL can be enriched with dietary supplements to compensate for certain anticipated nutritional inadequacies. The second element, a complement to supplementation, should be devising health and nutrition education programmes for refugees. (NB, in response to recommendations, UNHCR promptly purchased vitamin A capsules for distribution to the refugees).

\section{Acknowledgements}

We wish to thank the SIGHT and LIFE Task Force for donating standard laboratory chemicals. Thanks are due to the phlebotomists from the Badia Health Directorate who helped in blood sampling and processing.

This study was funded by UNICEF Amman office.

\section{References}

1. Beaton G et al. Appropriate uses of anthropometric indices in children. A report based on an ACC/SCN workshop. Geneva, WHO, 1990, (ACC/SCN Series, Nutrition Policy Discussion Paper No.7).

2. Ghassemi H. Growth of young children-strategies for monitoring and promotion. UNICEF report on the informal consultation held in New York, March 31-April 1. New York, UNICEF, 1985.

3. United Nations ACC/SCN Sub-Committee on Nutrition/ International Food Policy Research Institute. The world nutrition situation. Geneva, World Health Organization, 2000 (4th ACC/SCN report).

4. Katz J et al. The importance of age in evaluating anthropometric indices for predicting mortality. American journal of epidemiology, 1989, 130(6):1219-26.

5. Underwood BA. Overcoming micronutrient deficiencies in developing countries: is there a role for agriculture? Food and nutrition bulletin, 2000, 21(4):356-60.

6. Powell CA et al. Relationships between physical growth, mental development and nutritional supplementation in stunted children: Jamaican study. Acta paediatrica, 1995, 84:22-9.

7. Underwood BA. Perspectives from micronutrient malnutrition elimination/ eradication programmes. Bulletin of the World Health Organization, 1998, 76(Suppl. 2):34-7.

8. Messr E. Ending hidden hunger: a policy conference on micronutrient malnutrition. Food and nutrition bulletin, 1992, 14(1):62-4.

9. Underwood BA, Arthur P. The contribution of vitamin A to public health. FASEB journal, 1996, 10 (9):1040-8.

10. Sommer A, Davidson FR. Annecy Accords. Assessment and control of vitamin A deficiency: the Annecy Accords. Journal of nutrition, 2002 ,132 (9 Suppl.):2845S-50S.

11. Measuring change in nutritional status. Guidelines for assessing the nutritional impact of supplementary feeding programs for vulnerable groups. Geneva, World Health Organization, 1983.

12. Sullivan KM, Gorsein J. ANTHRO documentation, version 1.01. Joint Collaboration of the Division of Nutrition-Center for Chronic Disease Prevention and Health Promotion/CDC, USA, and the Nutrition Unit/WHO. Geneva, World Health Organization, 1990.

13. Orapin B et al. Dietary assessment of refugees living in camps: a case study of Mae La Camp, Thailand. Food and nutrition bulletin, 2003, 24(4):360-7.

14. Assessment of adult undernutrition in emergencies (report of an SCN Working Group on Emergencies special meeting). Nairobi, Kenya, April 2001.

15. Filteau SM et al. Influence of morbidity on serum retinol of children in a community-based study in northern Ghana. American journal of clinical nutrition, 1993, 58:192-7.

16. Thurnham DI et al. Using plasma acute-phase protein concentrations to interpret nutritional biomarkers in apparently healthy HIV-1-seropositive Kenyan adults. British journal of nutrition, 2008, 100:174-82.

17. Catignani GL, Bieri JG. Simultaneous determination of retinol and alpha-tocopherol in serum or plasma by liquid chromatography. Clinical chemistry, 1983, 29(4):708-12.

18. Food and Nutrition Board, Institute of Medicine, and National Academies. Dietary reference intakes (DRIs): acceptable macronutrient distribution ranges. Washington DC, National Academies Press, 2002.

19. Khatib IM. High prevalence of sub-clinical vitamin a deficiency in Jordan: a forgotten risk. Food and nutrition bulletin, 2002, 3(23Suppl.):228-36).

20. Pike RL, Brown ML. Dietary standards. In: Pike RL, Brown ML, eds. Nutrition, an integrated approach, 2nd ed. New York, John Wiley \& Sons, Inc., 1975:911.

21. Holland B et al. McCance and Widdowson's The composition of foods. Letchworth, UK, Royal Society of Chemistry, 1991. 